\title{
THE SIGNIFICANCE OF EXPERIMENTAL MURINE LEPROSY AND SCREENING TEST IN STUDIES ON CHEMOTHERAPEUTIC AGENTS FOR LEPROSY
}

\author{
(Abstract of Special Discourse Presented at the 29 th General Meeting of \\ the Japanese Leprosy Association)
}

\section{Assist. Prof. Shinji NISHIMURA}

The Research Institute for Microbial Diseases, Osaka University

There are two routes by which now therapeutics for leprosy may be discovered. One is the application of chemotherapeutic agents for tuberculosis in clinical use at the present to leprosy and the other is the experimental use of murine leprosy.

I have conducted studies on chemotherapeutics for leprosy since 1942, using murine leprosy. At first, it was believed that agents which were effective in murine leprosy would also have an effect in leprosy as in the case of chaulmoogra oil which is quite effective in both human and murine leprosy. Recently it has become more and more clear, however, that this does not necessarily hold true and agents may differ in their action between human and murine leprosy. Studies on other aspects, especially the biological reactions have also revealed many points of differences between human and murine leprosy. It has become apparent that to conduct murine leprosy experiments for the purpose of seeking an anology with leprosy is mistaken.

A review of the studies of other investigators fails to show an agent with a superior effect in both human and murine leprosy and even in regards to the same agent the results are contradictory, some investigators reporting satisfactory effects while others report that it is ineffective and it is difficult to decide which is correct. Detailed studies have not been conducted on clinical value in regards to the experimental data obtained in murine leprosy, in the chemotherapy of leprosy and as cultivation and inoculation in animals of the leprosy bacillus are not yet possible, the majority of the investigators merely resort to making suggestions as to the possible effect of these methods.

Some investigators state that if the chemotherapeutics for murine leprosy cannot be directly tied to and applied in leprosy, this experiment would be useless to pursue but $\mathrm{I}$ believe that if an agent can be discovered which is effective in both murine and human leprosy, this can serve as a basis for investigating the mechanism of the drug, make possible other related experiments indirectly and otherwise open the way for clinical utilization.

In order to utilize murine leprosy for the discovery of chemotherapeutic agents for leprosy, the first problem is to find chemotherapeutics which would have an effect both in murine and human leprosy. It is therefore necessary to collect as many agents as possible which are effective towards murine leprosy. A screening method was devised according to a set standard in order to classify the various agents which have been synthesized or extracted by the chemists in a short time as possible.

The above is a rough outline of the investigation and the procedures and speculations are 
presented in the following order.

I. Bacteriological aspect of murine and human leprosy

II. Difference between murine and human leprosy from the viewpoint of biological reaction

III. Effect of chemotherapeutics in murine leprosy

IV. Relationship between tuberculosis, human leprosy and murine leprosy from the standpoint of effect of therapeutic agents

V. The role of murine leprosy in the chemotherapy of leprosy

VI. Standard for the screening test 


\section{癩化学療法剤の研究における \\ 鼠癩実験の意義とスクリーニングテストについて}

（第29回日本顀学会特別講演要旨）

助教授西村真二

(大阪大学微生物病研究所)

目次

はじめに

I 細菌学的方面に打ける瀨と鼠顁

II 生体反応の上から見た両者の異同

III 鼠瀨に対する薬剤の効果

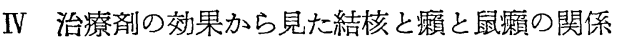

$\mathrm{V}$ 瀨の化学療法と鼠瀨実験の役割

VI スクリーニング法基準の考案

むすび

\section{はしがき}

瀨の化学療法凨を発見するカ法としては，凡そ2つの ルートが考光られる。その 1 つは既に臨床的に使用され

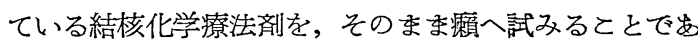
り，いま1つの方法は，鼠瀬を実験に利用するととで山 る。

私どもは1942年以来, 鼠瀨を用いて瀨化学療法剤の研 究を進めて来た, ところが最初, 瀬にかなりよく作用す る大風子油が, 鼠瀬にも相当効いたので, 化学療法剤の 鼠瀨実験も，その成績をそつくりそのまま瀨へめてはめ るととが出来るであるらと考えたが，研究が進むにつれ

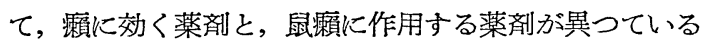
ととが次第に明か炕なり, 又他の方面の研究特に生体反 応の上に括いても㛓鼠瀨の異つた点がはつきりするに つれて, 単に癩へのアナロジーを求めるといら意味で鼠 瀨実験を行らことは間違いでめるととに気付いた。

また他の研究者が試みた数々の実験報告を検討してみ ても，瀨と鼠瀨に共通して勝れた効果まる薬剤はまだ発 見されていないし，同一種類の薬剤といえどる，研究者 によつて或は有効比或は無効と発表され，そのいずれを 信ずべきか，はたと困惑する場合がしばしばある。そし ててれら実験データの瀨化学療法に対する利用価値につ いては樑い思索を試みたものがなく, 瀨菌培養も, 動物
接種も不可能なために，止むを得ざる方法として，との 実験が幾何かの暗示を与えてくれるでめろらといら漠然 たる考えで利用している人が多いようである。 研究者の中には，鼠瀨での化学療法剤の実験成績が， 直接に瀨へ結びついて役立たなければ，乙の実験は利用 の価值なし，といらように割切つて考える人るめるであ ろらが，しかし私は，若しも瀨と鼠瀬に共通して効果ま る薬剤を見出すととができれば，その事実を橋渡しとし て, 薬剤のメカニズム追求とか，その他間接的に役立つ いろいろな実験を行らととができて，大い利用の道が 開けると思らのである。

このよらに，鼠瀨を利用する癩化療法鼡発見のルート では，先ず瀨と鼠瀬に共通して効果める化学療法剩を見 出すととが先決問題でめるから，その第 1 段の実験とし て鼠瀬に有効な物質を一種類でも多く集めることが当然 要求されるわけである。とてに括いて私どもは，化学者 が合成或は抽出した薬片の効果を，一定の基準に拠つて 出来るだけ短時間に撰別するととを目的として，1つの スクリーニング法を考案したのである。

以上がとの論文のあらすじで，乙とに至る思索と実験 のすじみちを，目次の順序で述べるととにしたい。

\section{I 細菌学的方面における癩と鼠癩}

櫴菌と鼠瀨菌は Mycobacterium としてその形態ばか りでなく，現在もな打試験管内培養不能の点までよく似 ている。細胞内における菌の配列に多少異つたところは めるが，その 1 個ずつを光学顕微鏡で調べても両者の相 違をつかみ難いし， Bishop and Suhrland22) は電子顕微 鏡によつて, 微細構造の上から, 瀨菌と他の培盖抗酸菌 との間には相違を認めたが, 瀨菌と鼠瀨菌は共に相似た 所見を呈したと述べている。

菌体成分については殆ど未踏のますで岁つたが最近 Nakamura ${ }^{49}$ はクロロホルム集菌法で集めた鼠瀨菌の化 学的成分について発表している。しかしまだ瀨菌の成分 については報告がないので両者を比較することはできな 
い。寺田 ${ }^{91)}$ は, 免疫学的な抗元構造の上から, 癩菌, 鼠 癩菌, 結核菌, 非病原抗酸菌の関係を第 1 図のようなシ エーマで現わしている。即ち鼠瀨菌は蛋白抗元で特異相

第 1 図 抗酸性菌抗元構造模型図 (寺田)

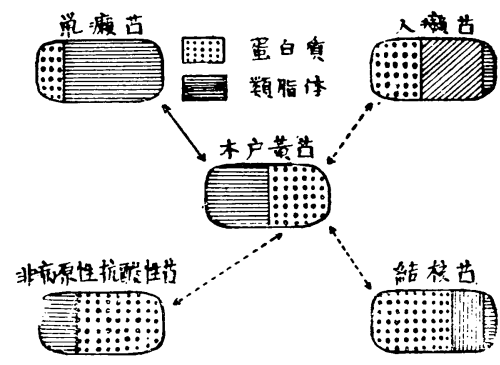

を示し，リポイド抗元では癩菌，結核菌と僅か心類属相 を, 非病原抗酸菌とは強い類属相を示している。攋菌は 蛋白抗元で結核菌, 非病原抗酸菌と強い類属相を現わし た。

菌のメタボリズムについては殆ど知られていないが， Hanks ${ }^{21) 22)}$, Gray'17) 等は，レプローマからとりだした生 の鼠癩菌を，warburg 検圧計によつてH T C を測定し， 極めて緩徐では岁るが，確実に内部代謝の行われている ことを証明している。しかし瘦菌についてはいまだとの ような方法によつて内部代謝が測定されていない。

次に私 57) 64) 60) どもの実験では，鼠瀨菌が結核菌と同 様に，イソニコチン酸ヒドラジットに対し抵抗性のでき るととを証明した（第2.3図）。それ故にこの菌が結核菌 などと同様生活環境への適応性を備えているととは想像 に難くない。けれども瀨菌の薬䩹抵抗性については，ま だ確かな証拠は挙げられていない。

以上のように細菌学的な面, 殊に発育関係多る物質 代謝では，癩菌も鼠瀨菌も全く暗黒の中に打かれている

第 2 図ヒドラジッド感受性鼠瀨菌の 発症抑制成績

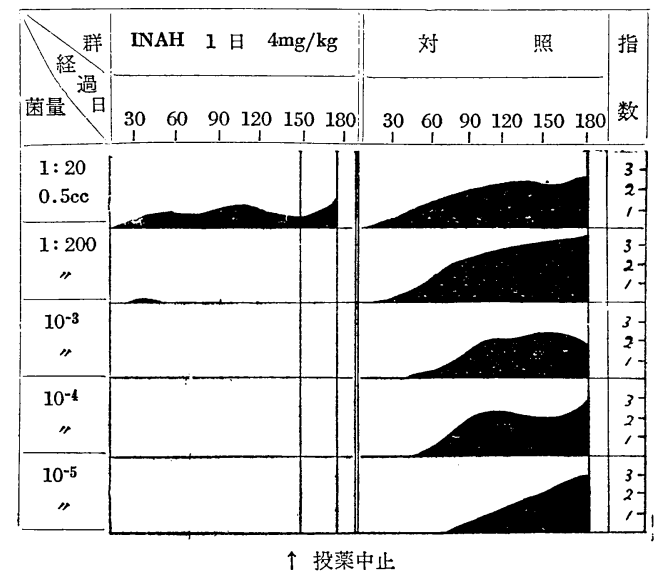

第 3 図ヒドラジッド抗抵性鼠癩菌の 発症抑制成績

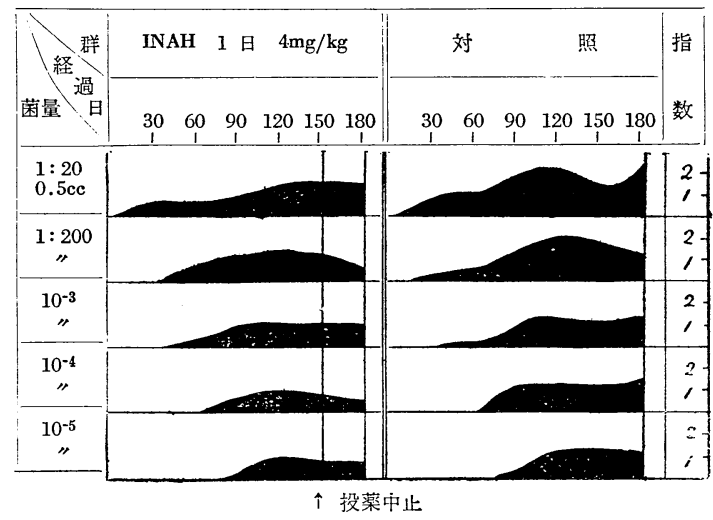

が，ただ形態上非常によく似ているととと，宿主の一定 細胞内に颃いてのみ増殖するといら生活環境の類似性か らみて，或は代謝の面にも一部に共通したととろがある のではないだろらか，と想像して見たくなる。

\section{II 生体反応の上から見た癩と鼠癩}

とれについては私どもの多数の研究がある。その業績 から主重要な点を拾い上げて見ると, 病理組織学的に 50) 81) 89)瀨と鼠瀬が最もよく似た点は，どちらも菌を 充満した癩細胞が或は鼠癩細胞が中核となつて瀨性肉芽 即ち瀨腫 (Leproma)を形成しているととである。しか しとれを細かく観察すると異つた点も甚だ多い。最も重 要な相違点は，癩では必ず未梢神経に病変を起すが，鼠

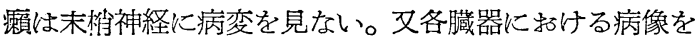
総括的に比較するに，籟菌は中肧葉系細胞のみならず外 胚葉系の細胞にも寄生増殖してととに病変を起すが，鼠 癩菌は中胚葉の間葉細胞にの夕寄生して病変を起す。其 の他人の結節瀬では血管炎, 結合織増生, 瀨細胞以外の 円形細胞浸潤があるに反し，鼠癗病巣にはこのような変 化はなく，たとえめつても甚だ軽い，そして瀨細胞は脂 肪化が極めて顕著でめるに反し，鼠癩細胞の脂肪化は常 に軽微で却つて壊死が速かに現われる。

癩と鼠瀨を血清蛋白組成 ${ }^{37)}$ 52) 53) の上から みると第 4 図の如く, Tiselius 電気泳動に扔いて，結節瀨血清中の 蛋白分劃は, 健康人に比してグロブリンが増量しアルブ ミンの減少が目立つが，鼠瀨では，重症例に括いても健 䐂鼠との間に何等の変動が見られない。

カルヂオライピンケフアリン抗元による瀨の血清反応 26）では凝集反応，補体結合反応ともに結節癩では第 1 表の如く可成り高率に反応するが，鼠癩では重症例と いえどす全く反応がない。 
第 4 図＼cjkstart瀨の血清蛋白分屋

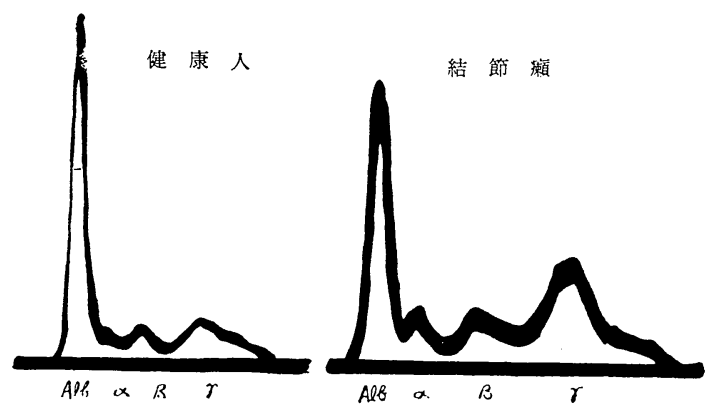

第 5 図 鼠瀨の血清蛋白分展
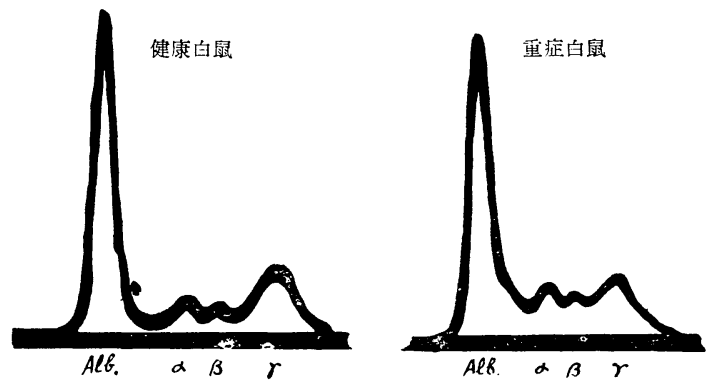

第1表 カルジオライピン，ケファリン抗元による の血清反応

結節頖 鼠 瀬

補体結合反応 +
凝集反応 +

このよ5に生体反応ではレプローマ形成といら共通点 を除いては, 相似点よりも寧ろ, 異つた点が多い。とれ は瀨菌, 鼠瀨菌といら寄生体の相違と, 人間と鼠といら宿 主の違い，との 2 つ因子に関係めるととと思らがとも かく Brinckerhoff ${ }^{3)}$ や川村 ${ }^{33)}$ が言つたような, 瀨と, 鼠 颓が，恰も人結核に対する牛結核のような近しい間柄で ないととは事実でめる。そしててのような生体反応の面 で相違のめるものが, 果して化学療法剤に対して同様の 効果を期待し得るであろらか, 殊に㾰病理の特徵ともい らべき, 瀨菌による末梢神経炎の存在は, 鼠瀬実験によ つて癩治療の上に何かを得ようとする場合, 最も考慮す べき点であるように思う。

\section{III 鼠攋に対する薬剤の効果}

わが研究室に括いて1942年以来今日まで引続いて研究 している鼠瀨を対象とした瀨化学療法郕の実験成樍並び に発表された諸家の成績を顧みるととにしたい。

1) 大風子油（1942 1945
発症抑制実験：ラットを用い鼠瀨菌接種後ヒデステリ ン 1 匹当 $0.04 \mathrm{cc}$ 週 1 回, $11 \sim 25$ 回, $3 \sim 8$ カ月に亘つ て注射したものでは有効であつた。文大風子油を 0.025 cc〜0.05cc ずつ週 1 回, 11〜28回, 4〜9 カ月間注射し た場合も有効に作用した。

諸家の研究では河村 - 内田 ${ }^{32)}$, 柛原 ${ }^{75)}$, 佐藤 $(\text { 勇 })^{77)}$,

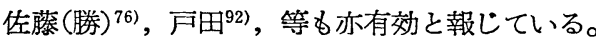

治療実験では F・koch ${ }^{35)}$ は有効といつたが，Markia nos ${ }^{41)}$ は無効と報している。

2）セフアランチン $\left(1945 \sim 46^{74)}\right)$

ラットに拮ける抑制実験：0.01 0.5 1 c 1 週 1 回, 20 〜30回，6〜8 カ月注射では無効であつた。

発症ラットに抢ける治療：0.01 0.5 cc 1 週 2 回, 15 〜5 回，5〜12 カ月注射は無効であつた。

諸家の実験中有効と報したものに，野平102)がある も, 柳 ${ }^{96)}$, 佐藤 (三) ${ }^{78)}$, 柳井 ${ }^{95)}$, 安元・高山年) は抑制 作用なしと言つて抢る。

3) 虹波（1947 48

発症ラットに対し $0.01 \sim 0.1 \mathrm{mg}$ 週 1 回，10 カ月に 40 回注射したが無効であつた。

4) プロミン (1947〜 49 41186) 87)

発症ラットに対する治療：ラットに対し $40 \% 0.1 \mathrm{cc}$ 1 週 2 回, 5 カ月間に 33 回 皮下注射したが無効, 又 30 $\%, 0.1 \sim 0.3 \mathrm{cc}$ 週 $3 \sim 6$ 回，5 カ月間に 33 回皮下注射 したがこれも無効であつた。

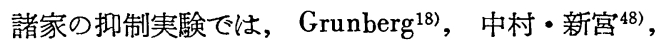
谷奥 ${ }^{85)}$, 中村 ${ }^{47)}$, 大国 ${ }^{11}$ Carpenter ${ }^{4)}$, 占部 - 高 ${ }^{94)}$, Hobby・Hanks ${ }^{25)}$ ，が有効と報じ，佐藤・真山等 ${ }^{79}$ が無 胶とした, 又治療実験では Gomes ${ }^{16)}$, Cowdry ${ }^{12)}$ ，は有 効としたが，佐藤・真山等並に Carpenter は効なしとし た。

5) ダイアゾーン

発症抑制実験; 大国 ${ }^{71)}$, Chang6) 等はこのを有効とし たが，北村 • 谷奥他， ${ }^{34)}$ ，佐藤・真山年， Grunberg • Schnitzer ${ }^{18)}$ ，Carpenter ${ }^{4)}$ は効果を見なかつたと。

6) プロミゾール

発症抑制実験：谷奥85) は有効でめつたといらが，佐 藤・真山等79 は無効といら。

7) $\operatorname{D~D~S~}\left(1955^{63365)}\right)$

発症排制実験：マウスに対し， $27 \mathrm{mg} / \mathrm{kg}$ を 1 週 6 日 3 カ月間経口投与した結果は僅かに有效であつた。諸家 の成績では有効を報告したものに Hobby・Hanks ${ }^{25}$, Lc-

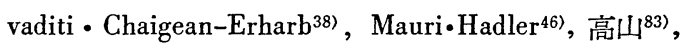
吉永 ${ }^{100)}$ があり，無効と発表せるものにGrunberg・Schni 
tzer $^{18)}$, Chang ${ }^{6) 7)}$, Barnett ・ Bushby ${ }^{1)}$, 佐藤・真山 ${ }^{80)}$ が ぬる。

\section{8) D H S $\left(1954^{59)}\right)$}

発症抑制実験：マウスに対し $50 \mathrm{mg} / \mathrm{kg}$ を週 6 回，3 カ月間経口投与したが無効でめつた。

9) P A S $\left(1955^{59)}\right)$

発症抑制実験：ラットに対し $25 \mathrm{mg} / \mathrm{kg}$ 週 6 回， 5 カ 月間 I N A H或は S M と共に経口投与したが，本猟の影 響を認めなかつた。文治療実験に㧊いても同様であつ た。

諸家のらち安元 ${ }^{97)}$, 吉永・加来 ${ }^{101)}$ は有効と報じてい るが, Grunberg・Schnitzer ${ }^{18)}$, Levaditi et al ${ }^{38}$, Chang ${ }^{8)}$, 佐藤・真山 ${ }^{79)}$ ，多賀 ${ }^{84)}$ (無効といつて扔る。

10) チビオン $\left(1950 \sim 51^{54)}\right)$

発症抑制実験：ラットに対しェチレングリココール溶 液として 1 日 $0.1 \sim 0.2 \mathrm{mg}$ 週 6 日， $7 \sim 8$ 力月皮下注 射したが無効であつた。

Grunberg - Schnitzer ${ }^{18)}$, Hobby • Hanks ${ }^{25)}$, Barnatt • Bushby $^{1)}$ ，安元 ${ }^{97)}$ 等は有効で㚣つたといい, 多賀 ${ }^{84)}$, Chang8) 等は無効といら。

治療実験：われわれがラットに対しエチレングリココ ール溶液として1日 $0.1 〜 0.2 \mathrm{mg}$ を週 6 回, 38〜81回， 4〜8 カ月に亘つて注射した成績は無効でめつた。然る に安元・平本 ${ }^{98)}$ ，は多少とも有効であつたという。

11） ストレプトマイシン $\left(1954^{58)}\right)$

発症抑制実験：ラットに対し，1 日 $5 \mathrm{mg}$ 週 6 回，5 カ月間皮下注射は可なり強く抑制した。マウスに対し $0.5 \mathrm{mg}$ 週 6 回， 5 カ月間注射した場合も同様に有効で 发つた。

諸家のらち有効と発表しているのは佐藤・真山 ${ }^{80)}$, 北 村・谷奥等 ${ }^{34)}$ ，多賀 ${ }^{84)}$, Hobby・Hanks ${ }^{25)}$, Chang6), Le vaditi等 ${ }^{38)}$, Barnett・Bsuhby ${ }^{1)}$ ，で，無効と報じている のは Grunberg • Schnitzer ${ }^{18)}$, Garpenter ${ }^{4)}$, Chaussinand ${ }^{9)}$ でする。安元・平本 ${ }^{98)}$ は治療でも僅かに有効という。

12）抗生物質

オーレオマイシン：西村・河野・増田 ${ }^{58)}$, Chang8), 等が無効と報じた。

パイオマイシン: Hobby・Hanks ${ }^{25)}$, 占部・野平 ${ }^{94)}$, 等が有効と発表。

カルボマイシン: Hobby・Hanks ${ }^{25)}$ ，は無効という。

テラマイシン: Chang8) (無効と発表。

クロロマイセチン：西村・河野・増田 ${ }^{58)}$, Chang8) に よつて無効と報告された。

アシドマイシン：西村・増田 ${ }^{58)}$ は無効と報告
13）イソニュチン酸ヒドラジッド（1052～54 $4^{55) 56) 60)}$ 61) 63) 64))

発症抑制実験：ラット及びマウスに対し $4 \mathrm{mg} / \mathrm{kg}$ を週 6 回，5 カ月間経口投与は，強力に抑制した。本刜の有 效性を報告せるものには Hobby・Hanks ${ }^{25)}$, Chang6), Grunberg • Titsworth ${ }^{19)}$, Mudrow-Reichenow ${ }^{45)}$, Chauss inand - Viette ${ }^{10)}$, Cruckshank ${ }^{11}$, Levaditi - Vaisman ${ }^{39)}$, Barnett - Bushby ${ }^{1)}$, Lew - Carpenter ${ }^{40)}$, Fegeler ${ }^{14)}$, Goulding ${ }^{103)}$ 市原・藤田 ${ }^{27)}$, 高山 ${ }^{82}$, 多賀 ${ }^{84)}$ ，川(口 ${ }^{31)}$ 等で,無 効を報告したものは一人もいない。

治療実験ではラットに対し $4 \mathrm{mg} / \mathrm{kg}$ 週 6 回, 5 カ月間 で著しく病症を改善した。高山 ${ }^{82)}$ 女有效と報じている。

14) 化学療法凨の併用 ${ }^{59) 60) 62) ~}$

$\mathrm{INAH}+\mathrm{SM}$ は，発症抑制及び治療共に極めて有効で 出つたが，作用の程度は INAH 単独投与に比して大差 なかつた。しかしとの併用によつて INAH 耐性の防止 に役立つた。

INAH+PASは，発症抑制には僅か心作用したが治療 に対しては無効であつた。即ち PAS の併用は INAH 単独に比して却つて効果の減退を見た。

INAH+TB-1 は，発症抑制には INAH 単独投与と殆 んど同一程度の効果が見られた。

INAH +Prominは, 発症抑制には INAH 単独投与と 同一程度の效果を見た。

SM+PAS は，発症抑制，治療共に顕著ではないがあ 第 6 図 化学療法剤による鼠瀬に対する効 果の治療抑制実験の成績一覧

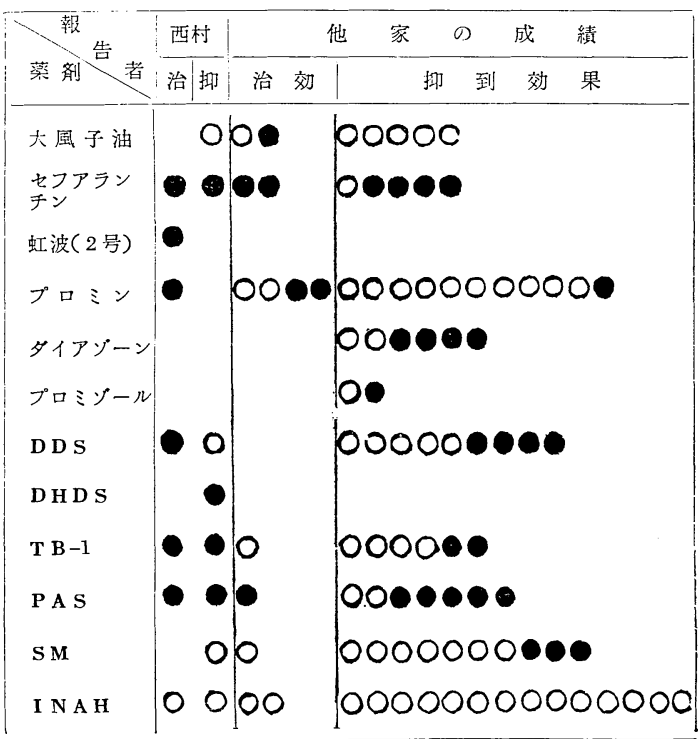

○は有 効（僅かに有効も含む） 
る程度有効であつた。文吉永・加来 ${ }^{101)}$ は，パスとヒド ラジットの化合物たるパシドラジットを用い鼠癩発症を 抑制したといら。

以上の成績を総括したものが第 6 図である。

この表で注目すべきは，鼠瀨に対するヒドラジットの 有効性が抑制にも，治療的にも全実験者によつて認めら れ無効を唱えたものは一人もないとと，他の薬㸞では其 の成樍が甚だ不定で効力の低いもの程成績が一致し 難 く, そのらちにも大風子油, ストレプトマイシン, プロ ミン，DDSなどは有効と報じたものが多いととでめる。

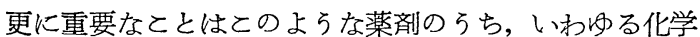

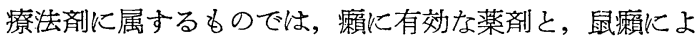
く作用する薬郕が一致していないととではる。

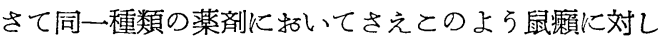
て成績の不一致があるわけは，各研究者の行つた実験方 法, 例えば投薬量, 投与方法は勿論のとと, 動物, 菌接 種部位, 菌量, 観察期間, 判定方法などに一定の基準が なく，各人別々の方法が採用されているとてろに最も大 きい原因があると思ら。第 2 表は最近の報告に見られた 実験方法の一覧で岕る。

第2表 諸家の実験法一覧

\begin{tabular}{|c|c|c|c|c|c|c|c|c|}
\hline 著 & 者 & 年 代 & 動 物 & 接種部 & 菌 & 量 & 期 & 定 \\
\hline Carpenter & 外 & 1949 & マウス & 皮下 & $1: 5$ & $0.2 \mathrm{cc}$ & $6 \mathrm{M}$. & Leproma, 菌分布 \\
\hline Grunberg & 外 & 1951 & マウス & 腹 肛 & $1: 10$ & $0.5 \mathrm{cc}$ & $4 \mathrm{~W}$. & 朋, 脾, 菌 分 布 \\
\hline 安 元 健 I & 児 & $"$ & ラット & 皮下 & $1: 20$ & $0.5 \mathrm{ce}$ & $8 \mathrm{~W}$ & Leproma, 菌分布 \\
\hline 中 村 昌 & 弘 & $"$ & ラット & 皮 下 & $1: 10$ & $0.3 \mathrm{cc}$ & $4 \mathrm{M}$. & Leproma 菌分布 \\
\hline 大国音三 & 郎 & 1952 & 、ラツト & 皮 下 & $1: 20$ & $0.5 \mathrm{cc}$ & $3-7 \mathrm{M}$. & Leproma 菌分布 \\
\hline Levaditi & & $"$ & マウス & 脳膜下 & 濃 & 厚 & $11 \mathrm{~W}$ & 菌 検 出, 組織変化 \\
\hline 西村真二 & 外 & 1953 & ラット & 皮 下 & $10^{2}-10^{4}$ & $0.5 \mathrm{cc}$ & $4 \mathrm{M}$ & Leproma，菌分布 \\
\hline Chang & & $"$ & マウス & 腹 腔 & $1: 30$ & $0.5 \mathrm{cc}$ & $3-4 \mathrm{M}$ & 淋巴腺臓器の I C E \\
\hline Barnett & 外 & $"$ & マウス & 静 脤 & 5000 万個 & $0.5 \mathrm{cc}$ & $6 \mathrm{M}$ & 脾の面積と菌分布 \\
\hline Goulding & & $"$ & マウス & 角 膜 & 高濃 & 度 & $4 \mathrm{M}$ & 内臟病変, 組織変化 \\
\hline 野 平 & 靖 & $"$ & ラット & 皮 下 & $1: 40$ & $0.5 \mathrm{cc}$ & $11 \mathrm{~W}$. & Leproma, 菌分布 \\
\hline 多賀 泰 & 雄 & 1954 & $\begin{array}{l}\text { ラット } \\
\text { マウス }\end{array}$ & 前眼房 & 濃厚 & 液 & $3 \mathrm{~W}$ & 虹 彩 小結 節 \\
\hline Hobby & 外 & $"$ & マウス & 腹 腔 & $1: 50$ & $0.4 \mathrm{cc}$ & $6 \mathrm{~W}$ & 脾 菌 数 計 算 \\
\hline Mudrow & 外 & $"$ & ラット & 莮粘膜 & 濃厚 & 液 & $6 \mathrm{~W}$ & 脾 菌 增 殖 度 \\
\hline Chaussinand & & $"$ & ラット & 皮下 & 涉厚 & 液 & $6 \mathrm{M}$ & Leproma, 分布菌 \\
\hline Levaditi & 外 & $"$ & ラット & 筋肉内 & 濃厚 & 液 & $12-18 W$. & 菌の体内分布 \\
\hline 吉 永・加 & 来 & $"$ & ラット & 皮 下 & $1: 20$ & $0.5 \mathrm{cc}$ & $3-4 \mathrm{M}$ & Leproma, 菌分布 \\
\hline 高 山 保 & 郎 & $"$ & ラット & 皮 下 & $1: 50$ & $0.5 \mathrm{cc}$ & $4 \mathrm{M}$ & Leproma, 菌分布 \\
\hline 中 島 & $\rightarrow$ & $"$ & マウス & 皮 下 & $1: 20$ & $0.2 \mathrm{cc}$ & $2 \mathrm{M}$ & 菌分 \\
\hline 市 原・藤 & 田 & 1955 & ラット & 皮下 & $\begin{array}{l}0.5 \% \text { V } \\
\text { 同一濃度 }\end{array}$ & $\begin{array}{l}\text { チンと } \\
0.5 \mathrm{cc}\end{array}$ & $5 \mathrm{M}$. & Leproma, \\
\hline
\end{tabular}

\section{IV 治療剤の効果から見た結核と鼠硕の関係}

現在用いられている瀨治療剤の大部分が，抗結核剤と 関連したものですり，文結核菌の物質代謝に関する知見 が，培養不可能な癩菌，鼠瀨菌の代謝機能を推測する上 に若干の暗示を与えているといら点から，結核及び癩に 対する化学療法剤の臨床的効果と, とれ等薬刱の鼠癩実 験成増を照し合せてととに治療剤の効果の面から結核, 瀨，鼠瀨の関係を考察して見たい。

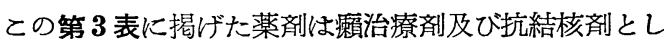
て過去或は現在使用されているもので山る。考察の便宜 上 3 群に分けた。
I群：大風子油のように作用機転はいますな阴明に されていないが,瀬菌よりも寧ろ生体に作用 (上川 $\|^{30}$ ) し て抗菌力を高めると,一般に考えられている薬蝺では,瀬 は勿論のとと結核 (宮川 ${ }^{43}$ ) にも或る程度の効果を認め て扣り, 又鼠瀨にも効果を示している。セフアランチン の作用機作については最初菌体えの影響（長谷川 ${ }^{23}$ ） と 考えられたがこれはまだ決定的ではなく, 寧ろ生体反応 力の変化であるとの考えを抱ける人が多いよらである。 虹波も亦一時結核 (今永 ${ }^{28}$ ) に用いられ, 瀨 (宮崎 ${ }^{44}$ ) にも試みられたが引続いてよい結果を得ていない。 
第 3 表 治療偊の効果から見た結核と癩と鼠癩の関係

\begin{tabular}{|c|c|c|c|c|}
\hline 群 & 薬 & 結核 & 穎 & 鼠獭 \\
\hline \multirow{3}{*}{ I } & 大風子油 & \pm & \pm & \pm \\
\hline & Cepharanthin & \pm & - & - \\
\hline & 虹 波 (2 号) & - & - & - \\
\hline \multirow{6}{*}{ II } & Promin & - & + & - \\
\hline & Diazone & - & + & - \\
\hline & Promizol & - & + & - \\
\hline & D $\quad$ D & - & + & - \\
\hline & Proethyl & - & + & - \\
\hline & $\begin{array}{llll}\mathbf{D} & \mathrm{H} & \mathrm{D} & \mathrm{S}\end{array}$ & - & + & - \\
\hline \multirow{6}{*}{ III } & $\begin{array}{lll}P & A & S\end{array}$ & + & - & - \\
\hline & $\mathbf{T} \quad \mathbf{B}-\mathbf{I}$ & + & + & - \\
\hline & $\mathbf{S} \quad \mathrm{M}$ & + & \pm & \pm \\
\hline & $\begin{array}{llll}\text { I } & \mathbf{N} & \mathbf{A} & \mathbf{H}\end{array}$ & + & \pm & + \\
\hline & Neoiscotin & + & $?$ & + \\
\hline & Marsilid & + & $?$ & + \\
\hline
\end{tabular}

以上の各薬舤では, 結核と癩及び鼠瀨の間に略々一致 した成績を現わしていると見てよいよらである。

II群：ジアミノ・ジフェニールスルホンを骨幹とした 一連のスルホン風では，いずれも癩にはよく作用してい、 るが，結核には大して効果がない，ただし実験的モルモ ット結核には有効との報告が多数ある15)24) 29)。然るに鼠 瀨には殆んど作用を示さないととは既に述べた通りです る。

III群：とのグループは現在結核治療㸞として臨床的に 使用されている化学療法剤であるが，このうちPASは， 瀨及び鼠瀨に有効との報告がない，TB-1 は瀨 ${ }^{58)}$ に作用 するが鼠㖽には無効，SM は瀨 ${ }^{72)}$ にも鼠瀨にも或る程 度奏効するが，結核に対するほど有効ではない。ヒドラ ジッドは結核同様鼠瀬にも強く作用するが瀨 ${ }^{42)}$ には一 時的に少効を見るのみ，其の他のヒドラジッド誘導体で 抗結核作用の強いものは鼠瀨にも亦効力を現わしてい る。

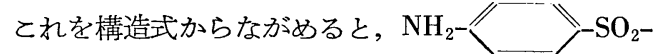
$\mathrm{NH}_{2}$ を骨幹とする諸種のスルホン郕と, $\mathrm{CH}_{3}$ $\mathrm{CONH}-1-\mathrm{CH}=\mathrm{N}-\mathrm{NH}-\mathrm{CS}-\mathrm{NH}_{2}$ か瀨によく作用 し，鼠触では $\mathrm{CONHNH}_{2}$

く作用している。結核では上記の TB-1，INAH の他に $\mathrm{NH}_{2}-1 \mathrm{COOH}$, 及び $\mathrm{SM}$ などがある。とのように
結核化学療法剤の構造が多種類に亘り癩の特効薬に比し て極めて幅の広いといらととは，それだけとの菌の代謝 作用が旺盛で機構が複雑なために，代謝阻碍を受ける面 も多いのではないかと予想される。しかし又別の面から 言つて，との表に揭げた薬剤はもともと結核を対象とし た実験で見出されたものであるから，結核に作用するも のが多いのは当然で, 若し将来鼠瀨実験によつて選び出 さたれた薬偊を以て磨と結核えの作用を比較すればそ とに異つた成績が生れて来るであろら。 以上の所見から一つのシエーマを描いて見た。

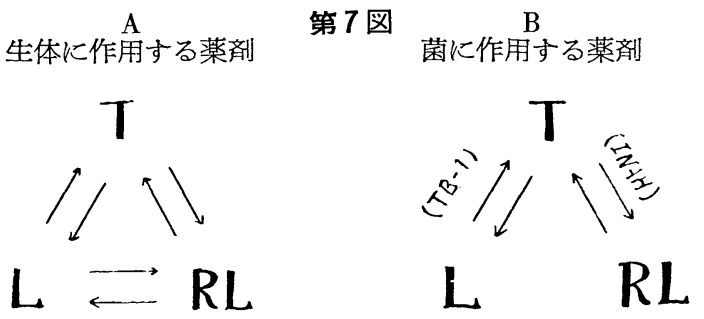

主として生体側に作用して抗病力を高めると考えられ る薬剤では第 7 図 $\mathbf{A}$ )の如く結核も瀨も，鼠瀨もほぼ共通 でめるように思えるが菌の代謝障碍を作用機作とする化 学療法剤では, 3 つの疾患に対する効果が一致し難い。そ のちちにもB）のように TB-1 は結核と瀨に共通, ヒド ラジッドでは結核と鼠瀬に共通しているので，見方によ つては，てれらの薬風によつて阻害される物質代謝の一 駒が両者に共存しているからではなかららかと想像した くなる。そして顧と鼠瀨の間にはをだ共通の阻害物質は 見出されていない。

\section{$\mathrm{V}$ 癩化学療法の研究における鼠癩実験 の役割}

ここで一先ず鼠癩実験が, 癩化学療法研究の上に果し 得る役割について述へようと思らが，その前にとれにつ いて，研究者が述べている主だつた意見を紹介して招き たい。

Chang 5) によれば, Domagk ${ }^{13}$ は鼠瓎によつて人瀨治 療に有用な物質を見出せないと述べていると言らが，彼 自身の考え方は明かでない。Grunberg等18)は，新たな 抗マラリヤ風が，鳥型マラリヤの実験によつて見出され たよらに, 鼠癩の利用によつて厄介な瀬治療研究の出発 点となし得るで㱔ろちと述へている。Barnett・Bushby1), も亦化学療法剤が鼠瀨菌に対して示すととろの有効性 は，人瀨菌に対しても適用できると卒直に述へてて扣る。 然し Hobby, Hanks 等25) はマウスやラットの鼠瀬で観 


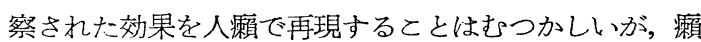
菌と同しょうに，細胞内で增殖する鼠瀨菌を以て罹患せ しぬた動物に対する薬版の実験成績は，臨床的な瀬治療 の発展を助けるでめろうと姼曲にその有用性を説いてい る。Hadler and Maury ${ }^{20)}$ は, 鼠瀬に関する多くの知見 にもとずいて，鼠瀨治療実験の結果はとの一部分だけし か瀨へ適用できないであろらが，といつて新たな抗瀨郕 の試験方法としての，乙の方法の利用価值を抹殺すると とはできないと。又师田 ${ }^{9293)}$ は，かつて大風子油の鼠 瀬実験に括いて癩と同様の好成績を得たととから，癩化 学剤の実臨に鼠癩を用らべきととを提唱したが，其の後 西村等がスルホン郕と INAH の効果か瀨と鼠䫐でくい 違つているととを指摘したととから，鼠制実験の今後の 研究に警告を与小ている。

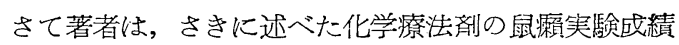
立倍細菌学的, 病理学的な知見を綜合してて, 次のような 考学抱くようになつた。

鼠瀨実験は，生体の抗病力を高める性質の薬㓮では， 瀬治療の予備実験としててれを利用するととが可能です ろら。しかし菌の物質代謝阻害を主な作用機転とする化 学療法剂では，たとい鼠瀬に有効な物質を見出したとし てもとれをそのまま癩に期待することはできない。しか らばこの鼠瀨実験は無意義かといらに，しかし決してそ らは思わない。とれについて具体的な例を挙げて見よ う。

私どもがさきに鼠顀有効薬剤として見出したヒドラジ ッドは，人瀨にはさ注ど顕著な効果を現わさないが， しかし鼠瀬化著しく有効なところから, 鼠瀨菌のヒドラ ジッド耐性獲得並にその防止の実験, 各種のヒドラジッ ド誘導体による作用基の追求，他の化学療法剤との併用 実験を行らことがでさて，その成績が間接的ではする が，瀨治療の上に示唆するととろ少くなかつたと思ら。 そしててのよらな間接的な応用のほが，一㬝重要なと とは, 癩と鼠瀬に効果の共通した化学療法蝺を探し出 し，その橋渡しの事実の上に，瀬菌に対する薬剤の作用 基団を追求して，新たな抗瀨物質の創造に確固とした指 針を与えたいととである。このよらな研究の進め方は瀬 菌培養や瀨菌の動物接種が不可能な現在, 䫀化学療法の 実験的研究方法として開かれている唯一の系統的な道順 であり，ててに今後の鼠㘔実験に負わされた最る重要な 使命が替んでいるのではなかろらかと私は考える。

\section{VI スクリーニング法基準の考案}

この基準を考案するに至つた第 1 の動嘰は，瀨と鼠瀨
に共通して有効な薬郕を 1 種類でも多く見出すととに関 連して，化学者が，新たな薬荗を合成又は抽出しても動 物実験が手間取つては，研究が啮滞するばかりでめるの で, 効果判定をできるだけ短期間に行ら必要のめるとと と，いま一つは，乙れまでの実験方法はその評価に一定 の基準が設けられてなかつたので，同一種類の薬㓮でも 実験者によつてその成績が違つていて, 評価の混乱が研 究の前進を阻んでいるようにさえ感したからである。そ とでスクリーニング法の考案に当つては次のような条件 を目標にした。

1. 判定期間の短縮

2. 手技簡単, 判定に客観性を持たせる

3. 少量の梅品にてテスト可能

4. 他のラボラトリーでも再現容易

5. 経済的負担の㪕隇

この条件を满たすため，基礎的実験として，先ず菌株 の選択, 接種部位, 接種菌量, 判定方法の簡易化, マウ ス系統の選択を行つて1つのスクリーニング法基準を考 案し，乙れを現在アメリカ方面にて多く行われているマ ウス腹腔内注射法，特化 Chang 法5) と比較して見るこ とにした。

\section{1）菌株の選択}

最も強力な菌株を選ぶため，現在日本で一般に用いら れている熊本株 (太田原・市原), 福岡株(戸田・占部) 警視庁株（内田三千太郎）の 3 つと，アメリカ方面にて 多く用いられているハワイ株 (Havard Medical School Hanks 氏より) の 4 株について, Virulence の比較実験 を行つた。詳細は交献 ${ }^{66)}$ に讓り,その結果を掲げると，

第 8 図 菌株の発症力比較 $\left(10^{-4} 0.2 \mathrm{cc}\right.$ 皮下接理 $)$

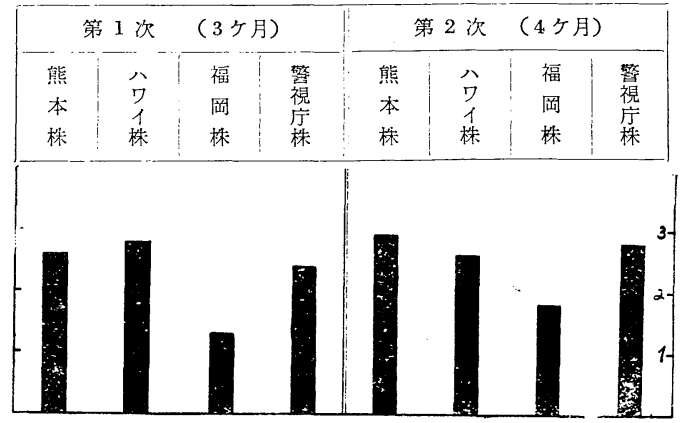

第 8 図のよらに，2回に亘る実験とも熊本，ハワイ， 警視庁の 3 株の間には著しい差を見ず，略々同一程度に 発症したが，福岡株は稍々劣つていた。それで 3 株のう ちいずれを採用してもよいわけであるが，国際性のある ハワイ株をとり上げるととにした。 


\section{2) 接種部位, と菌量}

自然鼠瀬で病巣の最も頻発するのは皮下の髹疎結合組 織とリンパ節で内臓では網状内皮系を富有する脾，肝で 岁る。従つてかよらな組織へ適量の菌を定着せしむるて とが発症を早めるに最適であろら。ところが諸家の実験 では第 2 表にも示したよらに皮下,腹腔,睪丸，静脈，筋 肉, 前眼房, 角膜, 脳膜下, 鼻腔など甚だ多くの部位が選 ばれて打る。しかし著者等は前記の理由と手技が簡単 な点で皮下接種, 腹腔接種, 静脈内接種の 3 つの方法を 選び, 発症が早く, 判定か確実且つ容易でするととを目 標としてマウスによつて比較を行らことにした。

実験の詳細は文献66) に讓りここには第 4 表について 要領を比較するに止める。

第 4 表 マウスに打ける実験要領の比較

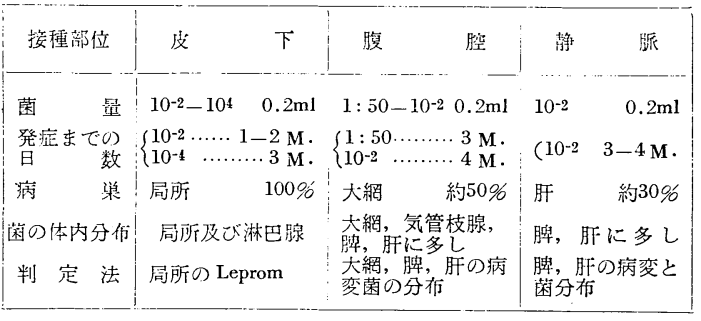

皮下接種： $10^{-2}$ 菌液（瀨腫乳風） $0.2 \mathrm{ml}$ では $1-2$ カ月後に, $10^{-4}$ 菌液では 3 力月目に局所に瀨腫を必発 し，肉眼的，臨床的汇判定がだる。菌は体表リンパ節 に多く分布する。

腹腔接種法: $10^{-2}$ 菌液 $0.2 \mathrm{ml}$ で約 4 力月，50 倍菌 液では 3 カ月目で内臟に病栄を発生し，とのらち大網に 最も強く現われるが，それでも肉眼的に病変を判定でき るのは約 50 \%に過ぎず, 肝, 脾も不定である。従つて 判定には藏器病変の程度のみを基準にすることはむつか しいから，菌分布との綜合判定にまつほかない。

静脈内接種法：この場合委李り濃厚な菌液は用いられ ないので $10^{-2}$ のものを $0.2 \mathrm{cc}$ 接種した。 3 ー4 カ月で 主として, 肝, 脾に病栄が生じた。しかしてれも全部で はない，肉眼的に確䒠に病変が見られたのは全例の約 $30 \%$ でめつた。それ故に判定は㵴器の菌分布について 顕微鏡的に調べる要がある。

以上のように，小量の菌で最も速か確実に発症する のは皮下接種で，との方法によるときは，接種局所の一 点に肉眼的に注意を集中すればよいので, 判定子他の方 法に較べて簡便である。特に下䠦部皮下接種が好都合で 女つた。

3）皮下接種法に抢ける成績判定法の簡易化
鼠癩化学療法剤の実験で，われわれ並びに諸家が従来 行つて来た判定法の要領は, 局所の癩腫の大さ（面積と 重量），リンパ腺及び内臟病変の程度とその組織学的変 化，菌の体内分布度などについて綜合的に評価していた のでめる。ところがこのよらな精密な判定手技は甚だ長 い期間と大きい労力を要し，最初の目標に揭げた最短期 間のスクリーニングといら条件を到底満たし得ないのて 一応上記の判定方法相互の関連性について検討し， 1,2 の最重要な点を観察すれば，他の個所はてれを省略して も全体の成績判定を誤らしむるととのない，最大公約数 的な判定規準なるものを考案しようとした。

実験の詳細は文献 67 ) に讓りその要点を記述すると,

a）皮下局所に生じた瀨腫の㹡がりは，第9図のよう に癩腫の重量と関連してている。そし.て菌分布指数とも関 連があると見てよいから，てれらのらち，拡がりのみを 基準として採用してても評価に大きい䛊りを来すようなと とは先ずないであろら。殊にマウスでは瀨腫の軟化が早 いため，とれを摘出秤量するととが困難な場合が多いの で，重量を基準に採択するととは実際䦗題として困難て ある。

第 9 図癩腫の拡がりとその重量，菌分布指数と の関係

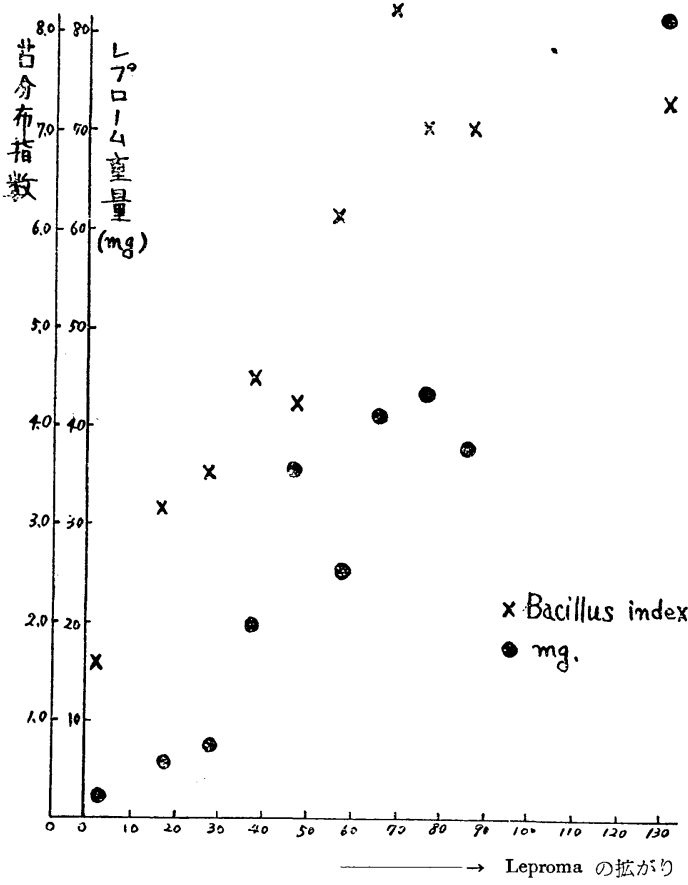

b）淋巴腺，内臟病変の程度を客観的な指数によつて 表示することは至難ですり，又接種菌液が稀薄 $\left(10^{-4}\right)$ でかつ経過か短い場合にはリンパ腺及び内臓にまで病変 
を見るととが極めて少いから，この場合内臓病変による 評価法は殆んど考慮の余地がない。

c) 脾の重量は，瀨腫並に菌分布指数と相関せず評価 の基準として用いる価値がない。

以上のような所見から，結局スクリーニングテストに 招ける最大公約数的な判定基準としてては，局所の攋腫の 大さ，特にその拡がりを経時的に測定することが最も合 理的であるととを知つた。

d) マウスの系統選択

ラット及びマウスは，その系統により，鼠瀨菌感受性 にかなり相違のあるとと，又同一系統といえども個体に よつて発症程度に差のあることは，顄々経験するところ でめる。とこではスクリーニングテストに最適のマウス を次のような条件を目安として選択した。

（1）鼠癩菌感受性が強く短期間に顕著な病巣を作るもの

（2）個体差が少く斉一比発庭するもの

（3）他の疾患に抵抗して長期の実験に耐え得るもの

（4）産仔率良好で大量供給可能なるの

そしてとの実験に供した系統は，NA1，NA2， $\mathrm{S}_{417}$ （大 阪純系動物研究所) ddT (武田薬品工業K.K, ) d br, DB $A, S$ (国立遺伝学研究所) $B$ (名大農学部家畜種学教室) SM（東京実験動物中央研究所）で出つた。

実験成績の詳細は交献 ${ }^{67)}$ 69) と讓りここに要点のみを 揭げると，第10図のよ5に感受性が強く個体差の尠い点 からは， B 系， dbr 系， $\mathrm{S}$ 系などが最も勝れているが， 死亡率尠く長期実験に耐え得ると云ら条件では ddT 系 SM 系, NAI 系, NA2 系などが好適でめつた。文大量 供給の面から云えば，大阪地方では $\mathrm{NA1}, \mathrm{NA} 2$ 系が適 格である。乙れまでわれわれが無頓着に使用していた杂佳 系マウスは総ての条件批いて上記の均一系マウス (Un iform Strain) に劣るものであつた。

第 10 図 マウスの系統と発症度 $\left(10^{-4}, 0.2 \mathrm{cc} 3\right.$ ケ月 $)$

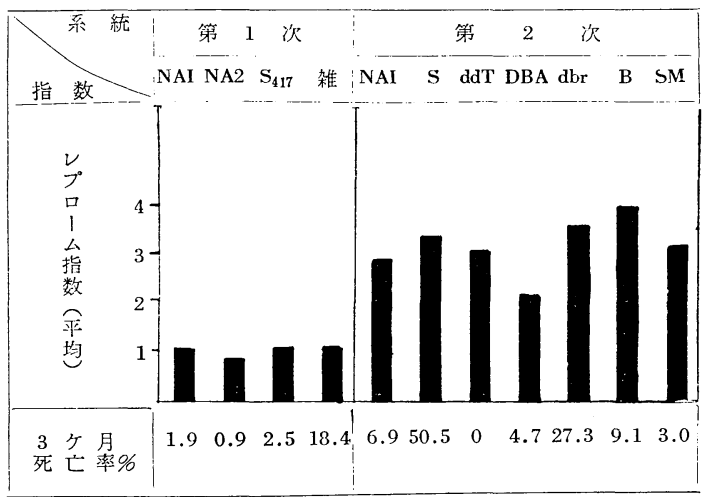

第 1 次実験では第 2 次よりも全体に発症がおくれた。
さて上記の系統の範同では最初に揭げた全部の条件を 満たし得るものは見出せなかつたが，B 系マウス（名大 農学部近藤博士 ${ }^{36)}$ によつて, 日本在来種から分離され た。黑色, 体重 $16-17 \mathrm{~g}$, 産仔率 5,6 , 育仔率 $74 \%$ ) は最 も有望な系統として将来の増産を期待するものでめる。

5）われ等の皮下接種法と Chang 氏腹腔接種法との 比較

先ず上述の基礎実験によつてわれ等が考案した方法 68) と, Chang 法5) を次に揭げる。

第 5 表A われ等の方法と Chang's 法との比較 西村, 岩佐 (皮下接種法) Chang (腹㙫接種法) 接種法 ハワイ株 $10^{-2} \sim 10^{-4}$ 生塩水 ハワイ株: $3: 10$ 生塩水乳郩 $0.5 \mathrm{cc}$ 乳戍 $0.2 \mathrm{cc}$

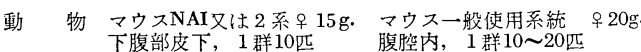

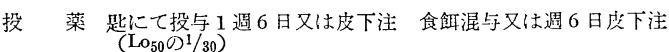

実験斯間 3 ケ月 3 ケ月

判定法 Lepromaの搪がり解剖による内䐵リンパ腺病変の

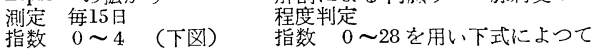

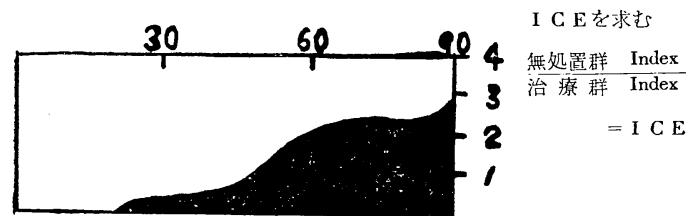

第 5 表B 西村，岩佐の Lepromaの拡がりによる判定基準

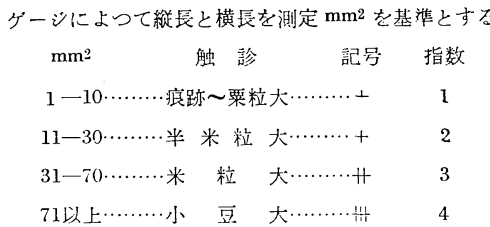

第 5 表C Chang 氏有效指数（ICE）の求女方 病変指数 接種部………………………... $0 \sim 2$ 大 網……………………..... $0 \sim 6$ 脂肪藮…….......................... $0 \sim 4$ 淋巴腚(肝只, 春椎, 気管支) ………0 2 脾 臈………………………... $0 \sim 4$ 肝 䑏………………………...... $0 \sim 4$

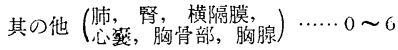

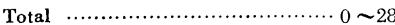
$\frac{\text { 対照群指数 }}{\text { 処置群指数 }}=\mathrm{I} \mathrm{C} \mathrm{E}$

この 2 つの方法を応用して（但し両方ともマウスは NA1 を用い投薬法は题にて経口的に行つた。） INAH （投与量 $4 \mathrm{mg} / \mathrm{k}$ )，ピラジナマイド(投与量 $133 \mathrm{mg} / \mathrm{k}$ ) 
DDS（投与量 $27 \mathrm{mg} / \mathrm{k}$ )，SM（投与量 $7.5 \mathrm{mg} / \mathrm{k}$ ) の抑 制作用を実験し，その結果を初めに掲げた 5 つの条件に 照して利用価值を比較して見た。（第12図）

第11図 西村・岩佐の判定法による成績

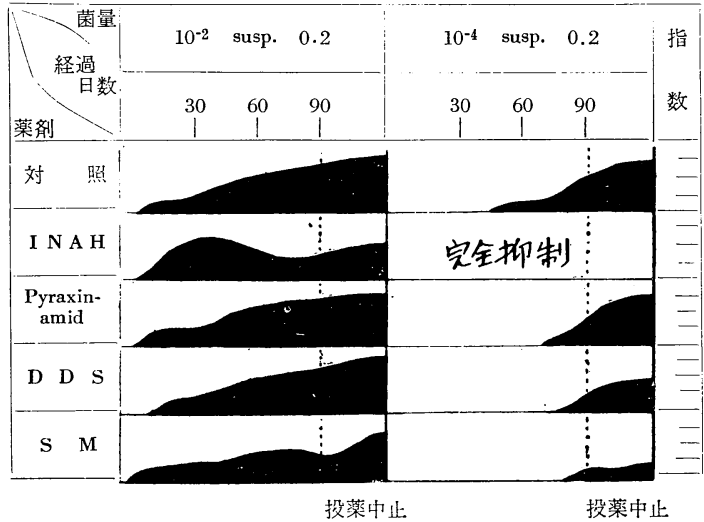

第12図 Chang. 氏効果指数 (ICE) で現われた成績

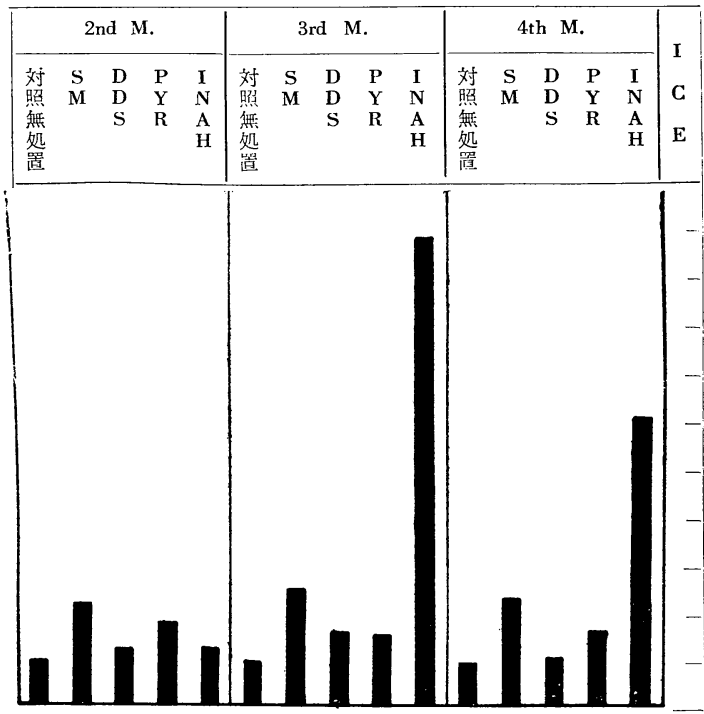

この 2 つの図に示されたところによると，われ等の方 法も, Chang の方法もともに 3 カ月で INAH が断然強 い効果を示し S Mがこれに次いでいる。このように両者 の所見は一応一致しているが，しかし其の間に㨟ける技 術的な長短について検討してみて次のようなととが云え る。

（1）時間的な面から見ると, 両方とる同様に 3 カ月て 判定できるが，皮下接種法では $10^{-2}$ と $10^{-4}$ の中間 菌 量即ち $10^{-3}$ 稀薄乳刋を将来使用するととによつて, 実 験を一層短期化する可能性が出る。
（2）皮下接種法では評価の目標が，接種局所の一点に 集約され，それが皮首面でゲージによつて正確に，しか も経時的に数回測定しヒストグラムに表現したものでめ るから，ただ 1 回の肉眼的観察よりも判定誤差が尠いと 思われる。一方腹腔内接種法では，解剖によつて病変を 検索し, 数個のリンパ節及び臓器の結節病变を肉眼的に 評価して，各部に怙ける指数の総和を更に ICE (Index of chemotherapeutic effect) によつて再評価するので, 指数の格差が甚だ大となり実際の効力差が誇張して表現 される危険が伴い易い。

（3）菌の濃厚液と稀薄液の $2 つ の$ 組合せを用いた皮下 接種法は，既に知られた INAH, SM, DDS などの発症 阻止作用の効力の限界を見事に示した。例えば INAH は $10^{-2}$ 菌液接種では不完全抑制でめるが，10 $10^{-4}$ 菌液接 種では完全抑制といらように。然るに $1 ： 30$ 濃厚菌液 ただ一種の腹腔接種では効力の限界を知るととがむつか しく，又効力の比較的弱い薬剤ではとの影響を知るとと が一層困難である。

（4）皮下接種法では，判定はゲージによつて測定でき るから技術的にそれほど熟練を要しない。ただ最初に菌 液の菌数を一定に保てるよう十分注意すれば，再現は極 めて容易でめる。Chang 氏腹腔法では，その評価が複 雑で, 毎常変化の強く現われる大網に0〜6の指数を与 えているので，何等の基準もなく，ただ肉眼的病変の程 度でのみ，このような幅の広い指数を評定することはな かなかむつかしく，従つてとの方法は，よ活ど手技に熟 達しない限り再現は容易でない。

（5）合成或は抽出された多種類の薬品，しかもその試 料が極めて少量のるのをスクリーニングする場合, $1: 3_{0}$ 乳剤のような濃厚菌液腹腔内注射よりも, 稀薄な $10^{-4}$ 菌液 $0.2 \mathrm{ml}$ を皮下接種した試獣について投薬を行ら方 が判定に有利である。

要するにわれ等の皮下接種法は, 簡単正確で再現容易 且つ少量の標品によつても判定可能でめる点に Chang 氏腹腔接種法よりも一日の長がめるように思ら。

\section{むす び}

以上を要約すると，鼠癩を癩化学療法凪の研究に役立 てるには，治療或は抑制効果を，そのまま直接に癩へ移 して利用するのではなく, 薬凨のメカニズムを追求し て，新たな癩化学療法鼡を創造して行く上に理論的な指 針を与えるととでなければならないと思う。けれどもそ れはむくまでも癩と，鼠瀨に共通の有効物質を見出した 上でのととでめつて，現在のところ，まだそのような化 


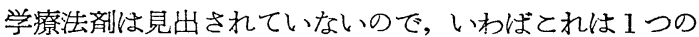
イメージともいらべきものであろら。

しかし私は, 瀨菌と鼠瀨菌は, 別個のものではある が，諸種の知見を綜合して両者の間には，代謝作用のど とかに颃いて相通ずる点が岁るにちがいないと考えるの で，とのイメージは実現の可能性があると信し，実現を 促進する1つの手段としてスクリーニング法を考案した のでもる。

そしてわれ等が考案したとのスクリーニング法は，そ の型が漸く出来上つたばかりであつて，てれから実際に 応用しているらちに不備の点も現われて来ると思らがそ れは今後の改善に俟ちたい。

終りに特別講演の機会を与えて下さつた会長上川豊園 長に謝意を表すると共に，私の鼠瀨研究に対し永年御指 導をいただいた阪大名誉教授佐谷有吉先生，同谷村忠保 先生に䔆んで厚く御礼を申上げ，多くの協同研究者に梁 甚の感謝を捧げる次第でめる。

\section{引用 文 献}

1) Barnett, M. and Bushby, S. R. M.: The activity of iso-nicotinic acid hydrazine in murine leprosy, Leprosy Rev. 24 (1953) 19-26

2) Bishop, F. W. and L. G. Suhrland: A comparative study by electoren microscopy of the morphology of Mycobacterium leprae and cultivable species of Mycobacteria, Internat. J. Leprosy 16 (1948) $361-366$.

3) Brinckerhoff, W. R.: Rat Leprosy. United States Pub. Health Bull. No. 30, (1910).

4) Carpenter, C. M., Stokinger, H. E. et al : Chemotherapy of murine leprosy, Amer. Rev. Tuberc. 60 (1949) 359-365.

5) Chang, Y. T.: Chemotherapy of murine leprosy. I. The use of mouse leprosy as the chemotherapeutic test, Internat. J. Leprosy 21 (1953) 47-56.

6) Chang, Y. T.: Chemotherapy of murine leprosy. II. The effects of streptomycin, sulfones and isonicotinylhydrazines on mouse leprosy, Internat. J. Leprosy 21 (1953) 57-71.

7) Chang, Y. T.: Chemotherapy of murine leprosy. III. The effects of nicotinamide and pyrazinamide on mouse leprosy, Internat. J. Leprosy 22 (1954) $331-346$.

8) Chang, Y. T. : Chemotherapy of murine leprosy.
IV. The effects of amithiazone (T. B.-1/698), PAminosalicylic Acid (PAS), B 283 (A Phenazine Pigment), Five Antibiotics and three Diphenylthiourea compounds on mouse leprosy, Internat. J. Leprosy 23 (1955) 167-179.

9) Chaussinand, R., Paris, C. et al : Essais de traitment par la streptomycin de l'infection murine due au bacille de Stefansky. Ann. Inst. Pasteur 75 (1948) 92-94. (Internat. J. Leprosy 17 (1949) 171-Abs).

10) Chaussinand, R., Viette, M. and O. Krug: Action de l'hydrazide de l'acide isonicotinique sur le rat infecte par le bacille de Stefansky, Ann. Inst. Pasteur 84 (1954) 431-434. (Internat. J. Leprosy 22 (1954) 253-Abs).

11) Cruickshank, J. C. : A trial of isoniazid in rat leprosy, Lancet (1953) 642 (Mar. 38) (Internat. J. Leprosy 22 (1954) 373-Abs.).

12) Cowdry, E. V. and C. Ruangsiri: Influence of promin, starch and heptaldehyde on experimental leprosy in rats, Arch. Path. 32 (1941) 632-640.

13) Domagk, G.: The Chemotherapy of tuberculosis with thiosemicarbazones. Colloquium on the chemotherapy of tuberculosis. Medical Research Council of Ireland, Dubulin, (1951) 136.

14) Fegeler, F.: Experimental investigations in the treatment of rat leprosy, (6th international congress of leprosy, read by title. Internat. J. Leprosy $\mathbf{2 1}$ (1953) 573.

15) Fritz, F. and T. Callomon: New derivatives of diaminodiphenylsulfone. Their therapeutic effect in experimental tuberculosis of guinea pigs, Amer. Rev. Tuberc. 47 (1943) 97-106.

16) Gomes, J. M. : Acao do promin sobre a mycobacterium de Stefansky; estude morfologico. Internat. J. Leprosy 16 (1948) 298-Abs.

17) Gray, C. T.: The respiratory metabolism of murine leprosy bacilli, J. Bact. 64 (1952) 305315.

18) Grunberg, E. and R. J. Schnitzer : Chemotherapy of murine leprosy, Ann. New York Acad. Sci. 54 (1951) 107-114.

19) Grunberg, E. and E. H. Titsworth: Preliminary note on the effect of isoniazid and iproniazid in 
murine leprosy, Amer. Rev. Tuberc. 67 (1953) $674-675$.

20) Hadler, W. A. and A. C. Mauri : Murine leprosy. I. A study of its pathogesis and evolution in rat inoculated by the peritoneal route. II. Experimental chemotherapy of leprosy: The use of murine leprosy for the experimental testing of chemotherapeutic compounds: Description of a technique, Internat. J. Leprosy 16 (1950) 67-77.

21) Hanks, J. H.: The biological significance of the Hydrogen transfer capacity of murine leprosy bacilli, J. Bact. 62 (1951) 529-537.

22) Hanks, J. H. and C. T. Gray: The application of metabolic studies to leprosy research, Internat. J. Leprosy 22 (1954) 147-160.

23）長谷川秀治：結核の化学療法関する研究特に 「ビスコクラウリン」型塩基の結核に及ぼす影響 （第 1 報） 昭和17年モノグラフ（セファランチン）

24) Hinshow, H. C. and W. H. Feldman: Treatment of tuberculosis, Use of sodium P. $\mathrm{P}^{\prime}$-diaminodiphenylsulfone $N$. $N^{\prime}$-didextrose sulfonate (promin) with notes on some toxic effects observed in man, J. Amer. Med. Associ. 117 (1941) 1066-1068.

25) Hobby, G. L., Hanks, J. H. et al : An evolution of chemotherapeutic agents in the control of experimental infections due to Mycobacterium, Amer. Rev. Tuberc. 16 (1954) 173-191.

26) 本多 一 他：カルヂオライピンケファリン抗原 による瀨血清反応について (II)，(III)，(IV) レプラ 21 (昭 27）120-124, 22（昭28），128-130, 23（昭 29) $18-22$.

27）市原, 藤田 他：鼠瀨の治療に関する研究（第 2 報）イソニコチン酸ヒドラジット単独並にストレプ トマイシンの併用による鼠瀨の発症阻止並に治療実 験レプラ 24（昭 30）33-39.

28）今永 一：外科的疾患儿対する虹波 (赤外感光色 素）の治療 日本医事新報 1194（昭21）315-316.

29) 今村, 堀, 広田: 結核化学療法の実験的研究 (101，102) 1. Promin の経口投与による海猽結核 の治療実験 2. Promin の皮下注射心よる海猽結核 の治療実験 大汳医学会雑誌 43（昭 19） 782-793 803-809.

30) 上川 豊：瀨治療法の現況（第13回日本瀨学会特 別講演）レプラ 11 (1940) $1-30$.
31）川口陽一郎：鼠㖽に対するイソニコチン酸ヒドラ ジットの影響 第 1 報, 第 2 報 レプラ 22 (昭28) 51,212 (学会抄)

32）河村正之, 内田 守: 大風子油及び其の製風並に 他の油剤の鼠癩に及ぼす影響に就てレプラ5（昭 9) $365-373$.

33) 川村六郎: 鼠瀨の研究 東京医学会雑誌 29 No. 12 (大正 4) $1-20$.

34) 北村, 谷奥, 藤田: 各種化学療法剤の鼠瀨に対す る効果 レプラ 20 (昭 26) 55 (学会抄)

35) Koch, F.: Die Rattenlepra und ihre Bedeutung für Klinik, Pathogenese und Therapie der menschlichen Lepra, Zbl. Haut und Geschl. 40 (1932) $433-4.44$.

36) 近藤, 姫野, 生駒, 葛城: マウスの育種儿ついて 農業技術研究所報告（畜産）第7号（昭 28）9-27

37）河野, 津上, 桜井 : 瀨性結節性紅斑の血清蛋白組 成並に白血球百分比に就て レプラ 21 (昭 27) 98 -102 .

38) Levaditi, C. and Chaignean-Erhard: Antibacterial action of streptomycin, PAS and DDS in mice infected with the Stefansky bacillus, Compt. rend. Soc. Biol. 145 (1951) 328-330. (Internat. J. Leprosy 20 (1952) 299-Abs.)

39) Levaditi, C., Vaisman, A. and H. ChaigneanErhard: Activite therapeutique de l'isonicotin hydrazide (INH) dans la lepre murine, Compt. rend. Acad. Sci. 236 (1953) 549-551. (Internat. J. Leprosy 22 (1954) 373-Abs.)

40) Lew, J. and C. M. Carpenter: The suppressive effect of isoniazid in murine leprosy, (6th international congress of leprosy, read by title, Internat. J. Leprosy 21 (1953) 571)

41) Markianos, J.: Essai de traitment de la lepre murine, Bull. Soc. Path. Exot. 22 (1930) 268272.

42）光田健輔他: 瀨に対するとドラジッド療法 レプ ラ 22 (昭 28) 262-269.

43）宮川米次 他：脂肪亚に脂肪酸による結核の療法 に関する研究 (第 1 報) 大風子油の結核菌に対する 抗菌性並にその静脈内注射による肺結核の治療法 日本医事新報 1643 (昭 $30 ， 10$ ) 3-10.

44) 富崎松記：感光色素（虹波）による㸊治療の現況 医学 1 (昭 21,11 ) No. 6 
45) Mudrow-Reichenow, L.: Die Wirkung von Neoteben (Isonicotinraure hydrazid) auf den Erreger der Rattenlepra, Ztsch. Trop, 5 (1954) 218 (Internat. J. Leprosy 22 (1954) 253-Abs.)

46) Mauri, A. C., Hadler, W. A. and C. M. Carvalho: Quimioterapia da lepra. I. Acao do 4-4'-diaminodiphenil-sulfone na lepra murina, Rev. brasileira Leprol. 19 (1951) 85-116 (Internat. J. Leprosy 21 (1953) 129-Abs.).

47) 中村晶弘：プロトミン及びビタミンの鼠癩発症に 及ぼす影響 レプラ 19 (昭 25) 5 号 21-23.

48) 中村, 新噯: プロトミンの皮下及び静脈投与の鼠 瀨発症に及ぼす影響 レプラ 20 (昭 26) 109-112

49) Nakamura, Masahiro: Attempts to approach to the clarification of chemical composition of Mycobacterium leprae murium. I and II, Kurume Medical Journal 2 (1955) 110—116, 3 (1956) 29—33

50) 西村真二：実験的鼠癩に抢ける内葴の病理組織学 的研究 (I)，(II)，(III)，(IV), (V). レプラ 13 (昭 17) 209-231， 13 (昭 17) 371-394， 13 (昭 17）600-624，14（昭 18）14-32，14（昭 18） 119 -139 .

51）西村, 河野 他：癩の化学療法に関する研究（第 6 報）攋及び鼠瀨に対するプロミンの効果とその作 用機転の追究 レプラ 19 (昭 25) 22-23.

52）西村, 河野: 鼠癩の血清蛋白組成について レプ ラ 21（昭 27）103-107.

53) Nishimura, S. and M. Kono: Studies on serum protein components of murine leprosy, Med. J. Osaka Univ. 5 (1954) 645-651.

54）西村, 河野, 青山, 高橋: 癩の化学療法に関する 研究 (第 9 報) 鼠瀨に対する邦製チビオンの効果 レプラ 21 (昭 27）26-29.

55）西村, 河野：同上（第10報）ヒドラジットの鼠 瀨に対する効果 最新医学 7 (昭 27) 1202-1207

56）西村, 河野, 増田：同 上（第11報）鼠瀨に対す るイソニコチン酸ヒドジットの影響 レプラ 22 (昭 28) $250-255$.

57) 西村, 増田：同上（第12報）イソニコチン酸ヒ ドラジットに対する耐性隻得について レプラ 23 (昭 29） 23-28.

58）西村, 河野, 増田：京上（第13報）鼠瀨に対す る抗生物質の影響 レプラ 23 (昭 29) 74-80.

59）西村，増田：同 上（第14報）鼠瀨に対する諸種
化学療法剤併用の影響 レプラ 23 (昭 29） 124一 133.

60) Nishimura, S. and T. Masuda: Studies on the chemotherapy of leprosy. On the resistance of the murine leprosy bacillus againts INAH and prevention of INAH resistance by the combination INAH and SM, La Lepro 24 (1955) Selected articles $1-7$.

61) 西村, 河野, 増田他: 同 上（第15報）イソニュ チン酸ヒドラジッド誘導体の鼠瀨発症阻止作用 レ プラ 23 (昭 29) 287-291.

62）西村, 増田：同 上（第16報）鼠癩菌のストマイ 而性と化学療法剤併用投与による I N A H 耐性防止 について レプラ 23 (昭 29) 345-348.

63）西村, 増田他：同上（第17報） I N A H 及びD D S の鼠瀨治療実験，特に大量投与試験 レプラ 24 (昭 30） 7-9.

64）西村，增田 他：同上（第18報）イソニコチン 酸ヒドラジット投与量と鼠癩菌の耐性との関係につ いて レプラ 24（昭 30）402-404.

65）西村, 増田, 岩佐: わ的等のスクリーニング法に よる諸種抗菌斉の抗鼠瀨作用 レプラ 24（昭 30) 432 (学会抄)

66）西村, 岩佐：鼠瀨化学療法のスクリーニングテス トに関する研究（其の1）鼠瀬菌株の選択並儿接種 部位と菌量の検討 レプラ 24（昭 30）156-165.

67）西村，岩佐：闰上（其の 2) 皮下接種に抢ける 成績判定方法の簡易化と使用マウスの系統について レプラ 24 (昭 30） 405-415.

68）西村，岩佐：同 上（其の 3) 余等の皮下接種法 と Chang 氏腹腔内接種法の比較実験並に討論 レ プラ 25 (昭 31) 1-14.

69）西村，中尾，岩佐：鼠瀨実験とマウスの系統 実 験動物異報 4 (1955) 27-28.

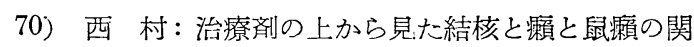
係 レプラ 25 (昭31) 115 (第23会瀬戸内集談会抄)

71) 大国音三郎：実験鼠瀨並に結核の化学療法関す る研究 医学研究 21 (昭 26) 974一984.

72）犀川一夫：瀨の化学療法们関する研究 瀨代対す るストレプトマイシン療法 医療 7 (昭 28) 213217.

73）佐谷, 谷村, 西村他：癩の化学療法関する研究 （第 1 報）鼠瀨儿対する大風子油の治効 レプラ 15 (昭 19）289-292. 
74）佐谷, 谷村, 西村他: 攋の化学療法に関する研究 （第 2 報）セフアラチンの鼠攋に対する効果 レプラ 16 (昭 22) 11-12.

75）榊原五百枝：大風子油有効成分の吥究（第 2 報） 大風子 $2 ， 3$ 成分の鼠瀨に対する効果 レプラ $\mathbf{5}$ (昭 9) 354 (学会抄)

76) 佐藤 (勝), 佐藤 (勇) : 鼠瀨と治療薬 レプラ 6 (昭 10) 119-120 (学会抄)

77）佐藤勇蔵：諸種治療薬の鼠瀨に及ぼす影響に就て 皮膚科泌尿器科雑誌 43 (昭 13) 315-321.

78）佐藤三郎：セファランチンを以てせる人瀨, 鼠癩 の治療経験 レプラ 18 (昭 24) 特別号 29（学会 抄)

79）佐藤, 真山他：癩の化学療法 レプラ 19 (昭25) 1 号 35 (学会抄)

80）佐藤, 真山：瀨の化学療法に関する研究（続報） レプラ 20（昭 26）54 学会抄

81）志水靖博：癩と鼠癩の異同に関する病理組織学的 研究 阪大医誌 6 (昭 28) 85-94.

82）高山保郎：I N A H投与の鼠瀨の発症阻止並びに 治療効果について レプラ 23 (昭 29) 71-73.

83）高山保郎：筋注用 DDS 及び Promin 投与の鼠瀨 発症並に治療効果について レプラ 6 (昭 30) 432 (学会抄)

84）多賀泰雄：鼠癩に括ける治療偊の効果測定法につ いて レプラ 22 (昭 28) 211 学会抄

85）谷奥喜平：(特講) プロミン並に類似化合物によ る瀬治療の共同研究 レプラ 19 (昭 25) 5 号, 21 -23 .

86）谷村, 西村, 神原他：プロミンの鼠瀨に対するわ れわれの実験成績 化学療法とホルモン療法 2（昭 24) $98-101$.

87）谷村, 西村, 河野他：再びプロミンの鼠瀨に対す るわれわれの実験成績 東京医事新誌 67 (昭 25) No. $2,3-4$.

88）谷村, 志水他：TB-1 の癩に対する治療効果 レ プラ 20 (昭 26) 203-206.

89) Tanimura, T. and S. Nishimura: Studies on the pathology of murine leprosy, Internat. J. Leprosy
20 (1952) 83-94.

90) Tanimura, T. and H. Honda et al : Studies on serum reaction in leprosy (Part 5) (will be published in Internat. J. Leprosy).

91）寺田正中：抗酸性菌の抗元分析と其の免度学的鑑 別診断 レプラ 15 (1944) 12-53.

92）戸田忠雄：瀨の実験的研究（其の 2) 瀨の化学療 法の研究に鼠癩を応用するととを提唱す 日本医学 及び健康保険 3318 (昭 18) 203-205.

93) 戸田忠雄：第26回日本獺学会討論 レプラ 22（昭 28) 214 . (学会抄)

94）占部 他：鼠瀨の化学療法に関する研究 瀨研究班協議会報告（昭 $30,10,16$ )

95）柳井正記：瀨の化学療法に関する実験的研究 第 2 編 数種化学物質の鼠癩に及ぼす影響 レプラ 20 (昭 26） $70-93$.

96) 柳 駿：瀨の実験的研究（その 4) 鼠瀨に及ぼす 植物油，T. R. 及びセファランチンの影響 医学研 究 21（昭 26）104-106.

97）安元健巟：PAS 並以 Tibion の鼠癩発症並儿管内 鼠癩菌に及ぼす影響 レプラ 20 (昭 26) 106-108

98）安元，平本：チビオン，パス，ストレプトマイシ ンの単独韭にそれらの併用投与の鼠瀨治療効果につ いて レプラ 21 (昭 27) 23-25.

99）安元，高山：ストマイ，パス，チビオン，プロミ ン及びセファランチンの単独並にそれ等の併用投与 の鼠癩治療効果 レプラ 22 (昭 28) 18-22.

100) 吉永敏夫：DDS 及び Promin の鼠癩発症に及ぼ す影響 レプラ 24 (昭 30) 432 (学会抄)

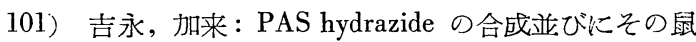
攋発症に及ぼす影響 レプラ 23 (昭 29）68-71.

102) 野平 靖: 鼠瀨の化学療法汇関する研究（第 1 報）プロマセチン，プロエヂール及びセファランチ ンの単独竝にそれ等の併用投与の鼠癩発症阻止並儿 治療効果について レプラ 22 (昭 28) 236-242.

103) Goulding, R., Robson, J. M. and Rees, R. J. W. : Intracorneal murine leprosy and its response to isoniazid, Lancet I (1953) 423 424 (Internat. J. leprosy 22 (1954) 37-Abs) 